\section{The Empire Marketing Board and Scientific Research.}

THE second report of the Empire Marketing
Board, covering the period May 1927-May 1928, which has just been published by H.M. Stationery Office (price 1s.), is a further indication of the importance which the Home Government now attaches to scientific research in connexion with the development of the resources of the Empire. The Empire Marketing Board was established in 1926 for " the furtherance of the marketing of Empire produce in the United Kingdom," and realised from the first that success depended largely upon the support given to scientific research and economic investigations and their extension to new fields. In last year's report the Board could only indicate its first approaches to the network of problems with which it was faced. Its tentative policy had still to be endorsed by the British overseas governments. It had still to stimulate those governments to create the necessary local machinery for the eo-ordination of research and the application of newly won knowledge to the better production and marketing of Empire crops.

In the present report the Board is able to record substantial progress, and while it is true that the greater proportion of its grants for research is still being made to institutions in Great Britain-because their comparatively advanced stage of development fits them for undertaking research work of general application-in the past twelve months it has been able to extend its grants to other countries and to new fields of science. The Imperial Agricultural Research Conference assisted the Board in this direction.

Details are given in an appendix to the report of the new schemes which the Empire Marketing Board is committed to support. Provision has been made for a grant of $£ 22,000$ per annum towards the cost of a Colonial Advisory Council of Agriculture and Animal Health, and the formation of a Colonial Agricultural Service with a specialist wing for research work and an agricultural wing for administrative work, conditional upon five times this sum being provided by colonial governments. A capital sum of $£ 18,500$ has been provided for chartering and equipping two trawlers to carry out investigations, under actual sea conditions, into the handling of fish at sea with the object of improving methods of preservation. A new station is being erected at East Malling for cold storage experiments on a semi-commercial scale in connexion with fruit. $£ 30,000$ is to be expended on adequate accommodation for the Department of Entomology at the Natural History Museum, and $£ 12,000$ on the erection of a new building to house the Imperial Bureau of Mycology upon a site which will enable it to retain its close connexion with the Royal Botanic Gardens at Kew. The government of Southern Rhodesia is now a participant in the scheme for the investigation into the mineral content of natural pastures, with special reference to soil deficiencies and their effect on the growth and strength of live-stock. The Ontario Agriciüultüurăl Collegge at Guelph is receiving a grant on a pound for pound basis for poultry research. A Plant Breeding and Seed Research Station is being established at Palmerston North in New Zealand. The government of Sierra Leone is being assisted to establish an experimental fruit farm in connexion with bananas and grape-fruit, and the Fiji government is being encouraged to undertake an investigation aiming at the improvement of methods of cultivation, handling, drying, and grading of copra.

Among other new projects for which grants have been made are : a geophysical survey of certain areas in Australia; the Great Barrier Reef Expedition; researches into the fundamental problems of sheepbreeding and determination of effective standards of raw wool to be carried out at the Animal Breeding Research Department, Edinburgh, and the Research Association for the Woollen and Worsted Industries, Leeds; an investigation into the nature of the variations in the vitamin content of cod-liver oils. The Empire Marketing Board is to be warmly congratulated on the manner in which it has disbursed its funds for the past two years.

\section{University and Educational Intelligence.}

Manchester.-The following appointments have been made in the Faculty of Technology : Mr. H. V. Lowry to be lecturer in mathematics; Mr. Thomas Bevan to be lecturer in mechanical engineering; $\mathrm{Mr}$. Horace Spibey to be assistant lecturer in spinning : Mr. N. W. Coe to be assistant lecturer in mechanical engineering.

Mr. F. H. Rerd, formerly of Northampton Polytechnic and now head of the Engineering Department at Sunderland Technical College, has been appointed head of the Engineering and Building Trades Department of the Borough Polytechnic, London, S.E.1. He will succeed Mr. G. E. Draycott, who is retiring at the close of the current session after thirty-one years in south London.

The Governors of Loughborough College, Leicestershire, invite applications for the award of five open scholarships in the faculty of engineering, each of the annual value of $£ 75$. The scholarships are open to British subjects situate in any part of the Empire, and are tenable at Loughborough College for the period of the full diploma course. Further particulars and application forms may be obtained from the College Registrar, to whom all forms of application must be returned not later than Mar. 28, 1929.

A NEW publication, Wessex, is not, as its name might imply, to deal at large with the area denoted by the name of the old Saxon kingdom resuscitated by Thomas Hardy. It is " an annual record of the movement for a University of Wessox based on University College, Southampton." It has been produced by members of the staff, students and friends of the College, and in part is devoted to descriptive accounts of the work of its academic departments. The greater part of the first number, however, is taken up by articles of a more general interest, some, but not all, of a local flavour. While Mr. O. G. S. Crawford deals with "Wessex," for example, Sir Mark Hunter discusses the ending of Shakespearian tragedy and Prof. E. W. Patchett reproduces a lecture on Faust. Two subjects, however, inevitably loom large, one the movement for a University of Wessex, on which Dr. C. G. Montefiore and Principal Vickers write, and the other Thomas Hardy, who was himself keenly interested in the movement. His life, work, and influence are here considered from many sides in a number of articles by personal friends and others. In the appeal for funds for the University, it is stated that a sum of somewhere about half a million will be required to provide building, equipment, and endowment -a very moderate sum when everything is taken into consideration and having in view the objects which it will be possible to achieve in an area which, at present, is but poorly served intellectually. Appeals to the purse of the public are numerous, but few are more worthy of support or more likely to repay the generous benefactor than this need of Wessex.

No. 3064, VoL. 122] 